\title{
Enhanced calcium carbonate-biofilm complex formation by alkali-generating Lysinibacillus boronitolerans YS11 and alkaliphilic Bacillus sp. AK13
}

\author{
Yun Suk Lee and Woojun Park ${ }^{*}$ (1)
}

\begin{abstract}
Microbially induced calcium carbonate $\left(\mathrm{CaCO}_{3}\right)$ precipitation (MICP) is a process where microbes induce condition favorable for $\mathrm{CaCO}_{3}$ formation through metabolic activities by increasing the $\mathrm{pH}$ or carbonate ions when calcium is near. The molecular and ecological basis of $\mathrm{CaCO}_{3}$ precipitating (CCP) bacteria has been poorly illuminated. Here, we showed that increased $\mathrm{pH}$ levels by deamination of amino acids is a driving force toward MICP using alkalitolerant Lysinibacillus boronitolerans YS1 1 as a model species of non-ureolytic CCP bacteria. This alkaline generation also facilitates the growth of neighboring alkaliphilic Bacillus sp. AK13, which could alter characteristics of MICP by changing the size and shape of $\mathrm{CaCO}_{3}$ minerals. Furthermore, we showed $\mathrm{CaCO}_{3}$ that precipitates earlier in an experiment modifies membrane rigidity of YS11 strain via upregulation of branched chain fatty acid synthesis. This work closely examines MICP conditions by deamination and the effect of MICP on cell membrane rigidity and crystal formation for the first time.
\end{abstract}

Keywords: Alkaline generation, Dual species $\mathrm{CaCO}_{3}$ precipitation, Bacteria- $\mathrm{CaCO}_{3}$ interaction, Branched chain fatty acid synthesis, Membrane rigidity

\section{Introduction}

Calcium carbonate precipitating (CCP) bacteria contribute to the geochemical cycle as they precipitate carbonate minerals, including calcium carbonate in nature (Douglas and Beveridge 1998). Formation of stromatolite is an example of calcium carbonate precipitation by cyanobacterial-bacterial mat communities (Paerl et al. 2001). There are four main environmental parameters that govern reaction kinetics for calcium carbonate precipitation: (1) $\mathrm{pH},(2)$ calcium $\left(\mathrm{Ca}^{2+}\right)$ ion concentration, (3) dissolved inorganic carbon (DIC) concentration, and [4] nucleation site availability (Hammes and Verstraete 2002). Bacteria influence these parameters through their metabolic activity, the production of biofilm, and

\footnotetext{
*Correspondence: wpark@korea.ac.kr

Laboratory of Molecular Environmental Microbiology, Department of Environmental Science and Ecological Engineering, Korea University, Seoul 02841, Republic of Korea
}

exopolysaccharide (EPS) formation, eventually leading to microbially induced $\mathrm{CaCO}_{3}$ precipitation (MICP). Bacterial metabolic pathways can create compounds that increase the solution $\mathrm{pH}$. These include photosynthesis, ureolysis, ammonification, denitrification, sulphate reduction, and formate oxidation are known to induce calcium carbonate precipitation (Hammes and Verstraete 2002; Ganendra et al. 2014). When resultant pH and DIC increases are accompanied by the aforementioned pathways in an environment with calcium ions, bacterial cell walls or their extracellular polymeric substances (EPSs) can serve as a nucleation site for precipitation reaction (Hammes and Verstraete 2002). Despite the fact that alkaline generating bacteria are ubiquitous in the natural environment, much of their microbial ecology remains to be investigated.

Bacteria can form biofilms in most environmental niches, and nearly all biofilm communities in nature 
comprise a variety of species (Elias and Banin 2012). Biofilms provide protection to cells when bacteria face fluctuating and harsh environmental conditions. They facilitate complex interactions between individual cells and an environment (Hall-Stoodley et al. 2004; Liu et al. 2016). The biofilm matrix is composed of multiple species and a mixture of components such as EPS, protein, nucleic acids, and other substances. The best studied one of these components is EPS (Davey and O'Toole 2000). The co-occurrence pattern of bacteria embedded in this matrix is determined by species interaction (Nadell et al. 2016). Biofilms not only contain biogenic substances, but also contain granules trapped from sediments (Riding 2000). EPSs generally possess metal binding properties, including $\mathrm{Ca}^{2+}$, because EPSs retain high molecular weight compounds that have charged functional groups (Bhaskar and Bhosle 2006). Therefore, multi-species biofilm in nature can act as a foundation for MICP. Previous studies have shown that EPS formed by biofilms is crucial when investigating bacterial physiological functions and activities (Giuffre et al. 2013; Braissant et al. 2003). These ex situ research efforts have also found that EPS could regulate spatial position of precipitation during mineralization. In the absence of microscale chemical gradients, nucleation models have estimated that crystals produced by biofilms can distribute randomly in EPS (Arp et al. 2001). Most current studies of biofilms and biomineralization suggest that precipitation of mineral appears on the biofilm surface primarily (Zhang and Klapper 2010). However, these studies and models are not suitable for in situ observation since information of mineral formation in biofilms, such as spatial patterns, are lacking. A recent study has developed a method for a real time, in situ biomineralization examination by imaging the biomineralized calcium carbonate within biofilms produced by Pseudomonas aeruginosa (Bai et al. 2017). However, interdisciplinary research studies of multi-species embedded biofilm, and its resultant MICP, have not been reported yet. Exploring the relationship between $\mathrm{pH}$ increasing bacteria involved in multispecies biofilm and calcium carbonate formation is important for understanding integral mechanisms of microbially induced calcium carbonate formation (MICP).

All living organisms, including bacteria, require metal elements for metabolic activities as metals have structural or catalytic roles (Ehrlich 1997). Among many metal ions, iron $\left(\mathrm{Fe}^{2+}\right)$, magnesium $\left(\mathrm{Mg}^{2+}\right)$, manganese $\left(\mathrm{Mn}^{2+}\right)$, zinc $\left(\mathrm{Zn}^{2+}\right)$, copper $\left(\mathrm{Cu}^{2+}\right)$, and $\mathrm{Ca}^{2+}$ are reported to possess important cellular functions in microorganisms (Roane et al. 2009). Various functions of metals, including $\mathrm{Fe}^{2+}, \mathrm{Mg}^{2+}, \mathrm{Zn}^{2+}$, and $\mathrm{Mn}^{2+}$, in bacterial cells have been well scrutinized (Andrews et al. 2003; Diaz-Ochoa et al. 2014). However, the role of $\mathrm{Ca}^{2+}$ inside bacteria remains far from clear (Norris et al. 1996; Dominguez 2004). Functions of $\mathrm{Ca}^{2+}$ in eukaryotes are well-established compared to those in prokaryotic cells. $\mathrm{Ca}^{2+}$ can act as a signaling molecule and a secondary messenger that is tightly regulated by the gradient between intracellular and extracellular $\mathrm{Ca}^{2+}$ concentrations (Islam 2012). It has been recently found that $\mathrm{Ca}^{2+}$ also possesses signaling functions in prokaryotic cells, including bacteria. $\mathrm{Ca}^{2+}$ concentration inside cell is tightly controlled. It is much lower in concentration than that in the outside environment (Dominguez 2004; Islam 2012; Dominguez et al. 2015). Furthermore, $\mathrm{Ca}^{2+}$-binding proteins pertaining EFhand motifs are found to be distributed among various bacterial species (Dominguez et al. 2015; Zhou et al. 2006; Rigden et al. 2011). Recent studies suggest that the delicate $\mathrm{Ca}^{2+}$ signaling found in eukaryotes might have evolved from prokaryotic signaling (Shemarova and Nesterov 2005; Case et al. 2007). Recent studies are unveiling specific roles of calcium in bacteria, such as $\mathrm{Ca}^{2+}$-signaling, $\mathrm{Ca}^{2+}$-binding proteins, motility, spore germination, quorum sensing, EPS production, and biofilm formation (Bertrand et al. 2010; Bilecen and Yildiz 2009; Cruz et al. 2014; Guragain et al. 2013; Johnson et al. 2011; Porsch et al. 2013; Sarkisova et al. 2005). It has been found that $\mathrm{Ca}^{2+}$-transporting ATPases, motility proteins, and two-component systems in bacteria can act in calcium concentration dependent ways (Bertrand et al. 2010; Bilecen and Yildiz 2009; Cruz et al. 2014; Guragain et al. 2013; Johnson et al. 2011; Porsch et al. 2013; Sarkisova et al. 2005). Because MICP occurs when $\mathrm{Ca}^{2+}$ exists in surrounding, CCP bacteria can provide a physiological model to examine bacterial response to $\mathrm{Ca}^{2+}$ when they produce calcium carbonate minerals.

In our previous study, a novel CCP bacterium Lysinibacillus sp. YS11 was isolated and characterized for its ability to produce calcium carbonate in solution (Lee et al. 2017). Unlike increase in $\mathrm{pH}$ level via ureolysis which has been broadly studied regarding MICP, strain YS11 was found to utilize pathways other than urea hydrolyses for $\mathrm{pH}$ increase of a solution (Yan et al. 2017). Here, we found that alkaline generation of YS11 was through ammonia production via deaminase activity. Alkaline generation from YS11 facilitated the growth of alkaliphilic bacterium Bacillus sp. AK13, which was isolated from the identical environment. It altered the morphology and amount of biofilm-bound calcium carbonate. Furthermore, we demonstrate that the precipitated calcium carbonate can modify membrane rigidity in bacteria by upregulating branched chain amino acid (BCAA) and branched chain fatty acid (BCFA) synthesis. 


\section{Materials and methods}

Genomic DNA extraction, whole genome sequencing, and genomic analysis of YS11

Genomic DNA of Lysinibacillus boronitolerans YS11 was extracted using Wizard Genomic DNA purification Kit (Promega, USA). Whole-genome sequencing was performed using Pac Bio RSII Single Molecule Real Time (SMRT) sequencing method (Pacific Biosciences, USA) with a SMRTbell template library in Chunlab (Seoul, South Korea) according to manufacturers' instructions. The complete genome was achieved using CLgenomics program provided by Chunlab. Gene annotation and assembly were conducted with NCBI Prokaryotic Genomes Automatic Annotation Pipeline. CLgenomics program provided by Chunlab and kegg pathway searching were used for genomic analysis of YS11.

\section{L. boronitolerans YS11 culture conditions}

For growth test of strain YS11, a seed culture was incubated in Luria-Bertani (LB) medium, which is composed of $1 \%$ tryptone (Bioshop), 1\% sodium chloride (SigmaAldrich), $.5 \%$ yeast extract (Bioshop), at $30{ }^{\circ} \mathrm{C}$ overnight with shaking at $220 \mathrm{rpm}$. Next, $1 \mathrm{ml}$ of the seed culture was transferred to a $1.7-\mathrm{ml}$ microtube and washed twice with phosphate buffered saline (PBS), which is composed of .08\% NaCl, .02\% KCl, .144\% $\mathrm{Na}_{2} \mathrm{HPO}_{4}, .024 \% \mathrm{KH}_{2} \mathrm{PO}_{4}$. Next, strain YS11 at density of $1 \times 10^{6} \mathrm{CFU} / \mathrm{ml}$ was transferred into $25 \mathrm{ml}$ of calcium acetate $(\mathrm{CaAc})$ medium (15.8 mM calcium acetate, .4\% yeast extract, .5\% glucose) or sodium acetate (NaAc) medium (15.8 mM sodium acetate, $.4 \%$ yeast extract, $.5 \%$ glucose) in a 50 -ml flask to observe the growth on $\mathrm{Ca}$-rich or $\mathrm{Ca}$-poor condition. Growth curves were generated based on colony-forming unit (CFU). The culture was serially diluted from $10^{\circ}$ to $10^{-8}$ using PBS for dilution. Then, $200 \mu \mathrm{l}$ of the diluted bacteria was streaked into pre-heated LB plates. The colonies were counted after $12 \mathrm{~h}$ incubation at $30^{\circ} \mathrm{C}$.

\section{RNA isolation and transcriptomic analysis by RNA-seq}

Total RNA was obtained from mid-exponentially grown YS11 cells $(6 \mathrm{~h})$ from $\mathrm{NaAc}$ and CaAc media using a RNeasy kit (Qiagen, Hilden, Germany) following the manufacturer's instructions. The extracted total RNA was then sent to Chunlab (Seoul, South Korea) for RNA sequencing and alignment. Ribo-Zero rRNA removal kit (Epicentre, Medison, WI, USA) was used for ribosomal RNA depletion according to the manufacturer's instructions. Libraries for Illumina sequencing were constructed with TruSeq Stranded mRNA sample prep kit (Illumina, San Diego, CA, USA) following the manufacturer's protocol. RNA sequencing was conducted on Illumina HiSeq 2500 platform using single-end 50 bp sequencing. Sequence data for the reference genome (Lysinibacillus boronitolerans YS11) were retrieved from the NCBI database. Quality-filtered reads were aligned to the reference-genome sequence using Bowtie2. The abundance of relative transcript was shown by reads per kilobase of the exon sequence per million mapped sequence reads (RPKM) defined as total exon reads/(mapped reads in millions $\times$ exon length in kilobases). Metabolic pathways were analyzed based on KEGG pathway analysis and BLAST alignment with proteins using CLRNASeq program provided by Chunlab.

\section{Isolation procedure for strain AK13}

To attain bacteria native to the environment of $L$. boronitolerans YS11, soil sample was amassed from the rhizosphere of Miscanthus sacchariflorus near Seong-

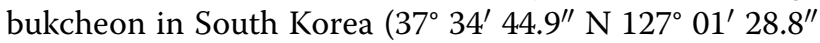
E) (Lee et al. 2017). A $1 \mathrm{~g}$ of soil sample was prepared and washed with PBS ( $\mathrm{pH} 7.5)$. It was then spread onto $\mathrm{pH} 13$ adjusted LB agar. Plates were cultured overnight at $30{ }^{\circ} \mathrm{C}$. Colonies that appeared on the agar plate were isolated and single colonies were roughly cocultured with YS11 in LB medium with three replicates to observe any difference in optical density (OD) compared to YS11 single culture. Cells were grown in PVC 96-well microtiter plates (BD Biosciences) at $30{ }^{\circ} \mathrm{C}$ and measured optical density at $595 \mathrm{~nm}\left(\mathrm{OD}_{595}\right)$ using biophotometer (Eppendorf, Germany). An isolate that showed a bump that had more than $1 \%$ increase in $\mathrm{OD}_{565}$ value in the growth curve during coculture was observed and named as AK13.

\section{Phylogenetic analysis of 16S rRNA gene sequence}

The 16S rRNA gene of newly isolated alkaliphilic strain AK13 was amplified using universal bacterial 16S rRNA gene primers 27F (5'-AGAGTTTGATCMTGGCTC AG-3') and 1492R (5'-TACGGYTACCTTGTTACG $\left.\mathrm{ACTT}-3^{\prime}\right)$. Polymerase chain reaction (PCR) was conducted with the following cycling conditions: $94{ }^{\circ} \mathrm{C}$ for $90 \mathrm{~s}$ followed up by 25 cycles of $94{ }^{\circ} \mathrm{C}$ for $45 \mathrm{~s}, 58{ }^{\circ} \mathrm{C}$ for $45 \mathrm{~s}$, and $72{ }^{\circ} \mathrm{C}$ for $45 \mathrm{~s}$, and finally an extension step at $72{ }^{\circ} \mathrm{C}$ for $5 \mathrm{~min}$. Sequence similarity with other bacteria was determined with EzTaxon program. A neighbor-joining tree was constructed using a distance matrix calculation method in MEGA 7. Bootstrapping was conducted with 1000 iterations. The fasta file of 16S rRNA gene sequence of strain AK13 was deposited at GenBank database (MK517564).

\section{Cocultivation for L. boronitolerans YS11 and Bacillus sp. AK13}

Strain YS11 was incubated overnight in $\mathrm{pH}$ 6.8 LB broth while strain AK13 was cultured in pH $8 \mathrm{LB}$ broth at $30{ }^{\circ} \mathrm{C}$ overnight. Cells were then washed twice with PBS. For 
coculture of YS11 plus AK13, $1 \times 10^{6} \mathrm{CFU} / \mathrm{ml}$ of overnight isolates were inoculated into YL medium composed of $.4 \%$ yeast extract and $.34 \%$ calcium-acetate at 1:1 ratio. For single culture of YS11 and AK13 each, $2 \times 10^{6} \mathrm{CFU} /$ $\mathrm{ml}$ of overnight isolates were inoculated into $\mathrm{YL}$ medium. They were incubated at $30^{\circ} \mathrm{C}$ with shaking at $220 \mathrm{rpm}$.

The growth rate of coculture and single culture was measured by counting colony-forming unit (CFU). Normal neutral LB agar was used as a selective medium for strain YS11 while LB agar with pH 12 was used as a selective medium for alkaliphilic strain AK13. Alteration of $\mathrm{pH}$ and unbound calcium ion concentration were measured using a pH electrode (Thermo Fisher Scientific, USA) and a calcium-ion selective electrode (ISE) (Thermo Fisher Scientific, USA), respectively. The $7 \mathrm{ml}$ volume of subsamples were removed from the master volume, over time for $24 \mathrm{~h}$. For these sub samples, organic matters were removed by centrifugation at $4000 \mathrm{rpm}$ for $10 \mathrm{~min}$ prior to measurements. These experiments were conducted in triplicates.

For coculture experiment in agar plates, two types of modified B4 medium, CaAc medium and NaAc medium, were used. Then $20 \mu \mathrm{l}$ of each YS11 and AK13 overnight cultures $\left(1 \times 10^{6} \mathrm{CFU} / \mathrm{ml}\right)$ were spotted on the edge and opposite sides of the plate and then cultured at $30^{\circ} \mathrm{C}$ for $24 \mathrm{~h}$.

\section{FE-SEM and FTIR for morphological analysis of $\mathrm{CaCO}_{3}$} Mineral from YS11 single culture or YS11 plus AK13 coculture in YL medium was dried in an oven drier at $100{ }^{\circ} \mathrm{C}$ overnight prior to FE-SEM analysis. The sample was placed onto a carbon tape for $1 \mathrm{~h}$ to be dried. After blowing unattached particles with nitrogen gas, samples were Pt-coated and analyzed with a Quanta 250 FEG FESEM (FEI, USA). For FTIR analysis, an oven dried sample was resuspended in distilled water and analyzed using ATR method in FTIR (Agilent).

\section{$\mathrm{pH}$ measurement in $\mathrm{pH}$ increasing condition}

To determine $\mathrm{pH}$ increasing mechanisms in various conditions, $10^{6} \mathrm{CFU} / \mathrm{ml}$ of overnight YS11 was inoculated into media consisting of either $.8 \%$ yeast extract or $.8 \%$ nutrient broth or MSB basal medium each supplemented with . $1 \%$ pyruvate, $.1 \% \mathrm{~L}$-serine, or . $1 \%$ pyruvate plus . $1 \%$ $\mathrm{L}$-serine. Total of $50 \mathrm{ml}$ volume culture was incubated in $100 \mathrm{ml}$ volume of Erlenmeyer flasks. $\mathrm{OD}_{600}$ and $\mathrm{pH}$ were measured in 24-h interval during their incubation at $30{ }^{\circ} \mathrm{C}$ with agitation at $220 \mathrm{rpm} .7 \mathrm{ml}$ volume of sub samples were taken out from three replicates and measured right away. For the optical density measurement, $10^{-1}$ dilutions were done for each sample.

\section{Ammonia measurement assay}

Ammonia concentration during incubation of YS11 in YL medium was measured using ammonia assay kit (SigmaAldrich). Briefly, supernatant $(50 \mu \mathrm{l})$ of YS11 cultured in YL medium was mixed with ammonia assay reagent $(500 \mu \mathrm{l})$ containing $\alpha$-ketoglutaric acid and NADPH. Then, $5 \mu \mathrm{l}$ of L-glutamate dehydrogenase was added to each sample and incubated for $5 \mathrm{~min}$ at $30{ }^{\circ} \mathrm{C}$. The absorbance of each solution was measured at wavelength of $340 \mathrm{~nm}$.

\section{CLSM analysis to examine biofilm and calcium carbonate development}

Biofilms from YS11 and YS11 plus AK13 were stained for 30 min with FilmTracer ${ }^{\mathrm{TM}}$ SYPRO $^{\circledR}$ Ruby biofilm matrix dye at room temperature and visualized using CLSM (LSM700; Carl Zeiss, Jena, Germany). FilmTracer ${ }^{\mathrm{TM}}$ SYPRO $^{\circledR}$ Ruby biofilm matrix stained biofilm cells were used to obtain confocal images under red fluorescent light (excitation wavelength: $450 \mathrm{~nm}$, emission wavelength: $610 \mathrm{~nm}$ ). Calcium carbonate was visualized under blue fluorescent light by reflection signal of excitation between 483 and $493 \mathrm{~nm}$ (Bai et al. 2017). Both biofilms and precipitated calcium carbonate were evaluated for height and density of morphology (C-Apochromat $40 \times / 1.20$ W Korr M27; Carl Zeiss).

\section{Biofilm formation assay}

Overnight cultures of YS11 and AK13, with the same condition mentioned in cocultivation section, were washed with room-temperature PBS twice at roomtemperature. Overnight cells were then inoculated into $1 \mathrm{ml}$ volume of YL medium to contain $2 \times 10^{6} \mathrm{CFU} / \mathrm{ml}$ of strain YS11 or mixture of YS11 and AK13 at cell density of $1 \times 10^{6} \mathrm{CFU} / \mathrm{ml}$ each in 48 -well microtiter plates. The volume of the cells inoculated was measured by converting $\mathrm{OD}_{600}$ value of the overnight cells and converting them to the standard $\mathrm{CFU} / \mathrm{ml}$ graph. Cell inoculated microtiter plates were then incubated at $30{ }^{\circ} \mathrm{C}$ with different time intervals $(24 \mathrm{~h}, 48 \mathrm{~h}, 72 \mathrm{~h})$ in static condition. Biofilms were stained with crystal violet dye using crystal violet staining assay (O’Toole 2011). Crystal violet attached to biofilms was dissolved in $95 \%$ ethanol solution. The optical density at $595 \mathrm{~nm}\left(\mathrm{OD}_{595}\right)$ was then measured for biofilm quantification using a multi-detection microplate photometer (HIDEX Sense, Finland).

\section{FAME analysis}

Fatty acids from YS11 cultured in NaAc and CaAc media were extracted. Fatty acids were then saponified and methylated to be transformed into fatty acid methyl esters (FAMEs). At first, the bacterial cells washed twice 
with PBS, and were harvested with centrifugation. The cells were resuspended in $1 \mathrm{ml}$ of saponification reagent into $15 \mathrm{ml}$ falcon tube. This was vortexed for $30 \mathrm{~s}$ and heated at $100{ }^{\circ} \mathrm{C}$ for $5 \mathrm{~min}$. The cells were once again vortexed for $10 \mathrm{~s}$ and heated at $100{ }^{\circ} \mathrm{C}$ for $25 \mathrm{~min}$. Then, they were heated at room-temperature for $1 \mathrm{~min}$ and $2 \mathrm{ml}$ of methylation reagent were added. This was vortexed for $10 \mathrm{~s}$ and heated at $80{ }^{\circ} \mathrm{C}$ for $10 \mathrm{~min}$. The solution was cooled at room-temperature for $1 \mathrm{~min} .1 .25 \mathrm{ml}$ of extraction solvent was added and vortexed for $10 \mathrm{~min}$ where the solution divides into two layers. The upper later was transferred into new $15 \mathrm{ml}$ falcon tube. $3 \mathrm{ml}$ of base wash solution was added and vortexed for $5 \mathrm{~min}$. The upper layer of the solution was finally transferred into GC vials. These extracted FAMEs were analyzed using an Agilent $7890 \mathrm{GC}$ system with a flow ionization detector and an HP-Ultra-2 capillary column (crosslinked $2.5 \%$ phenylmethyl silicone, $25 \mathrm{~m}, 200 \mathrm{~mm}$ i.d., film thickness: $.33 \mathrm{~mm}$ ). MIDI-2000 calibration standard was used to calibrate FAME values. FAMEs were identified and qualified using the Sherlock 6.0B MIDI software according to their equivalent chain value.

\section{FE-SEM/EDX analysis for $\mathrm{CaCO}_{3}$ nanoparticle formation}

YS11 was incubated in CaAc medium for 6 and $12 \mathrm{~h}$ at $30{ }^{\circ} \mathrm{C}$ prior to FE-SEM and EDS analyses. Cells were fixed first with low-strength Karnovsky's solution (2\% paraformaldehyde, $2.5 \%$ glutaraldehyde, and .1 M phosphate buffer, final pH 7.2) for $2 \mathrm{~h}$. Secondary fixation was done using $2 \%$ osmium tetroxide solution for $2 \mathrm{~h}$. These fixed samples were gradually dehydrated with ethanol $(30 \%$, $50 \%, 70 \%, 100 \%)$ for $10 \mathrm{~min}$ each and placed onto aluminum stub for 4 days to be dried at room-temperature. These samples were then coated with platinum and analyzed using field-emission scanning electron microscope Quanta 250 FEG (FEI, USA) and energy dispersive X-ray spectrometer (EDS).

\section{Bacterial strains culture deposition number}

A strain YS11 culture was stored in Agricultural Culture Collection (KACC) under number KACC 81048BP. A strain AK13 culture was stored in KACC with a deposition number of KACC 81070BP.

\section{Nucleotide and SRA sequence accession number}

The complete genome sequence of Lysinibacillus boronitolerans YS11 has been deposited in NCBI under the GenBank accession number CP026007.1. The RNA-seq of Lysinibacillus boronitolerans YS11 has been deposited in NCBI under the SRA number SRR8083459.

\section{Results \\ Complete genome sequencing of $\mathrm{CaCO}_{3}$ precipitating bacterium YS11}

Whole genome sequencing of Lysinibacillus sp. YS11 previously reported for its non-ureolytic calcium carbonate precipitation (Lee et al. 2017) was conducted in this study. A complete genome comprising 1 circular chromosome with the genome size of 4,584,915 base pairs and GC content of $37.70 \%$ was obtained (Fig. 1a). Until now, a total of 111 genomes from species belonging to Lysinibacillus genus have been sequenced, including a CCP strain Lysinibacillus sphaericus LMG 22257 (Yan et al. 2017). The genome of Lysinibacillus sp. YS11 and genomes of other Lysinibacillus species, including $L$. boronitolerans NBRC 103108, L. macroides DSM 54, L. xylanilyticus DSM 23493, and L. pakistanensis JCM 18776, was compared (Table 1). Average Nucleotide Identity (ANI) of strain YS11 with other species belonging to Lysinibacillus genus revealed that YS11 belonged to boronitolerans species, showing ANI of $99.87 \%$ (Table 2). The genome size of YS11 was $4.584 \mathrm{~kb}$, was $99.9 \%$ the size of L. boronitolerans NBRC 103108 (4.564 kb). L. boronitolerans YS11 possessed the highest number of tRNA genes (34) and rRNA genes (107) among the other four species. Similar to results from ANI analysis, analysis for the presence and absence of genes also verified that YS11 was closest to L. boronitolerans NBRC 103108 and the farthest from strain JCM 18776 (Additional file 1: Fig. S1A). YS11 also retained similar distributions of genes in COG category with strain DSM54, in which the most abundant genes were affiliated to amino acid metabolism and transport (E) (Additional file 1: Fig. S1B). Except L. pakistanensis JCM 18776, strain YS11 retained most abundant number of CDS related to amino acid metabolism and transport (E) COG group (Fig. 1b). Genes involved in ammonia production for possible alkaline generating pathway were searched in the genome of YS11. There are total of 35 genes that were directly involved in ammonia production (Table 3). When the number of genes involved in deamination of amino acids in the genome of $L$. boronitolerans YS11 was compared to that of NBRC 103108, a phylogenetically similar species, YS11 possessed about 3 times more genes of amino acid deaminases, suggesting species specific characteristics of basic compound production (Fig. 1c). Along with strain NBRC 103108, other Lysinibacillus species also showed smaller numbers of amino acid deaminases (Fig. 1c).

\section{Alkaline generation by YS11 is suitable for $\mathrm{CaCO}_{3}$ precipitation}

Ammonia concentration was measured during the growth of YS11 in YL medium. The increase of ammonia 


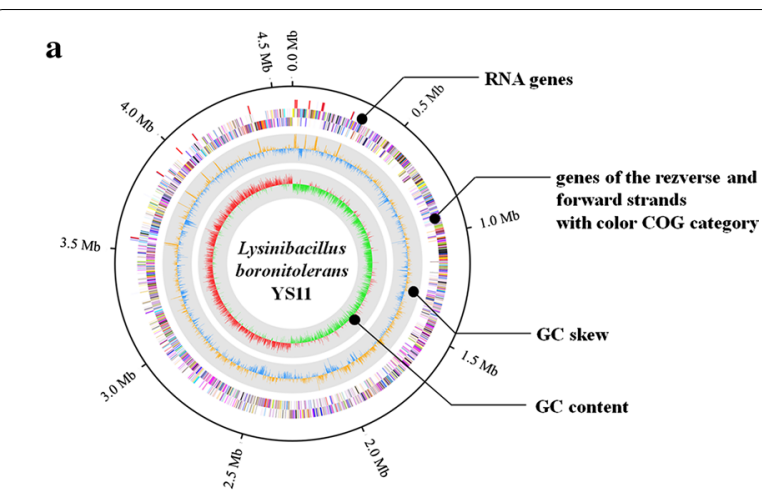

b

E: amino acid metabolism and transport
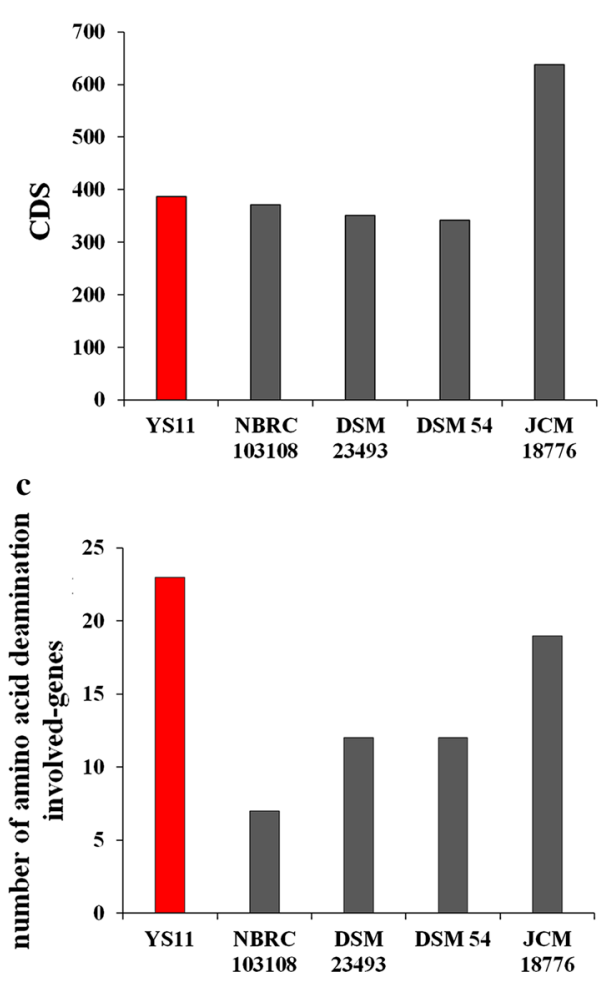

Fig. 1 a Circular genomic map of Lysinibacillus boronitolerans YS11. From the outside to the center are RNA genes, genes of the reverse strand, genes on the forward strand, GC ratio, and GC skew. Genes are colored according to their COG category. $\mathbf{b}$ Number of CDSs belonging to amino acid metabolism and transport group from YS11 with other Lysinibacillus species including L. boronitolerans NBRC $103108^{\top}$, L. macroides DSM 54 ' ${ }^{\top}$, L.xylanilyticus DSM 23493 ${ }^{\top}$, and L. pakistanensis JCM $18776^{\top}$. c COG category of Lysinibacillus species. $\mathbf{d}$ Quantification of CDSs involved in deamination of amino acids among amino acid metabolism and transport groups from Lysinibacillus species

concentration in accordance with $\mathrm{pH}$ increase suggested that ammonia production might be a major way for alkaline generation (Fig. 2a). Thus, alkaline generating pathways of non-ureolytic YS11 were analyzed using phenotypic and genomic approaches. Since yeast extract in YL medium is abounded with amino acids, $\mathrm{pH}$ change in two kinds of rich medium culture each supplemented with $.8 \%$ yeast extract and .8\% nutrient broth was measured (Fig. 2b). YS11 could increase the $\mathrm{pH}$ in both conditions, highly suggesting that deamination of rich amino acids provided by yeast extract in the medium was the key factor in ammonia production during this condition. Since yeast extract is an undefined complex component known to attain rich amino acids, transcriptomes during $\mathrm{pH}$ increasing conditions of $\mathrm{CaAc}$ and $\mathrm{NaAc}$ were analyzed. When data were trimmed with RPKM expressions higher than 100, genes involved in deamination of the following eight compounds were expressed: L-serine, glutamine, glutamate, aspartate, meso-diaminopimelate, porphobilinogen, alanine, cystathionine, and glucosamine-6-phosphate (Fig. 2c).

\section{Increase in pH level by YS11 induces interspecies interaction with alkaliphilic bacterium}

In order to observe interspecies interaction in biofilm mediated calcium carbonate formation, additional isolation from where YS11 had been found was conducted to explore species that is in cooccurrence with YS11. Alkaliphilic strains were targeted for screening procedure as L. boronitolerans YS11 promotes alkali condition during the growth, and strain AK13 was isolated. In the procedure, bacterial isolates with alkaliphilic properties were screened in pH 13 adjusted LB medium culture. After incubation, colonies formed in LB medium were further tested for coculture with strain YS11. The phylogenetic tree of strain AK13 was evaluated with 16S rRNA gene sequences, including strains showing high similarity (Additional file 1: Fig. S2A). Strain AK13 was phylogenetically affiliated with genus Bacillus. Its 16S rRNA gene sequence showed the highest similarity (99.88\%) with that of Bacillus hunanensis JSM $091003^{\mathrm{T}}$, Bacillus oshimensis DSM $18940^{\mathrm{T}}$, and Bacillus lehensis MLB$2^{\mathrm{T}}$. These 16S rRNA gene sequences of strain AK13 also shared high similarities with Bacillus xiaoxiensis JSM $081004^{\mathrm{T}}(99.25 \%)$ and Bacillus patagoniensis DSM $16117^{\mathrm{T}}$ (99.13\%). Strain AK13 was able to grow well without any inhibition at alkaline $\mathrm{pH}$ range from $\mathrm{pH} 8$ to $\mathrm{pH}$ 11 compared to its growth in $\mathrm{pH} 7$, showing an optimal growth at $\mathrm{pH} 8\left(\mathrm{OD}_{600} \sim .65\right)$. Its growth was inhibited at $\mathrm{pH} 7$ and $\mathrm{pH} 12$. AK13 strain was unable to grow at $\mathrm{pH}$ 6 (Additional file 1: Fig. S2B). This implies that AK13 is an alkaliphilic bacterium (with optimal growth in alkaline condition, unable to grow or its growth is hampered in neutral condition). On the other hand, YS11 showed optimal growth rate at neutral $\mathrm{pH} 7$. YS11 strain was able to grow at $\mathrm{pH} 6$ and at $\mathrm{pH} 9$, but not at $\mathrm{pH} 10$ and $\mathrm{pH} 11$ (Additional file 1: Fig. S2B). 
Table 1 Genomic features of $L$. boronitolerans YS11 compared with other Lysinibacillus species including L. boronitolerans NBRC $103108^{\top}$, L. macroides DSM 54 ${ }^{\top}$, L. xylanilyticus DSM $23493^{\top}$, and L. pakistanensis JCM $18776^{\top}$

\begin{tabular}{|c|c|c|c|c|c|}
\hline \multirow[t]{2}{*}{ Features } & \multicolumn{5}{|l|}{ Values } \\
\hline & YS11 & NBRC 103108 & JCM 18776 & DSM 54 & DSM 23493 \\
\hline Genome size (Mb) & 4.58 & 4.56 & 5.01 & 4.87 & 5.22 \\
\hline GC content (\%) & 37.7 & 37.6 & 36.3 & 37.7 & 36.5 \\
\hline Contigs & 1 & 81 & 73 & 15 & 13 \\
\hline CDS & 4602 & 4576 & 8211 & 4713 & 4884 \\
\hline rRNAs & 34 & 6 & 5 & 9 & 20 \\
\hline tRNAs & 107 & 52 & 74 & 86 & 100 \\
\hline
\end{tabular}

Table 2 Average nucleotide identity (ANI) of strain YS11 with other Lysinibacillus species

\begin{tabular}{ll}
\hline Strain YS11 & $\begin{array}{l}\text { Average } \\
\text { nucleotide } \\
\text { identity (\%) }\end{array}$ \\
\hline Lysinibacillus boronitolerans NBRC 103108 $^{\top}$ & 99.87 \\
Lysinibacillus pakistanensis JCM 18776 $^{\top}$ & 98.93 \\
Lysinibacillus macroides DSM 54 $^{\top}$ & 98.16 \\
Lysinibacillus xylanilyticus DSM 23493 $^{\top}$ & 97.27 \\
\hline
\end{tabular}

Further experiments were performed to observe interaction among these two different bacteria during cocultivation. These two strains were cocultured in neutral growth medium of $\mathrm{pH} 6.8$ to observe interspecies interaction in both liquid culture and agar plate culture (Fig. 3a, d). Yellow colony of AK13 also appeared in the agar plate culture when YS11 and AK13 were each spotted at the edge of the opposite side of the plate. To identify the cocultivation more specifically, each species' growth in $\mathrm{pH}$ varying $\mathrm{LB}$ selective medium, $\mathrm{pH}$ change, and unbound calcium concentration were measured. The growth of alkaliphilic AK13 in single culture was not detected throughout the experiment. Strain YS11 single culture grew to cellular density up to $10^{8} \mathrm{CFU} / \mathrm{ml}$, reaching its stationary phase at $9 \mathrm{~h}$ after incubation (Fig. 3a). On the other hand, when these two bacteria were cultured together at 1:1 ratio of initial cellular density of $10^{6}$ cell/ $\mathrm{ml}$, strain AK13 could retrieve its growth starting from $9 \mathrm{~h}$ after incubation (Fig. 3a). This result suggests $\mathrm{pH}$ increase by strain YS11 enables the growth of alkaliphilic AK13 during their cooccurrence. The $\mathrm{pH}$ of the coculture and that of YS11 single culture were both increased along with bacterial growth. The $\mathrm{pH}$ increases in coculture (up to $\mathrm{pH}$ 7.6) was less than that of YS11 alone (up to $\mathrm{pH} 7.9$ ) (Fig. 3b). Unbound calcium ion concentration gradually decreased with YS11 alone and YS11 plus AK13 coculture, although the coculture showed faster decrease in calcium concentration (Fig. 3c). No prominent decrease in calcium ion concentration was detected for AK13 single culture since there was no growth. However, a slight decrease of approximately $300 \mathrm{ppm}$ of calcium ions was found. This might be due to charge-charge interaction of initially inoculated cell wall and calcium ion (Fig. 3c). For the alkali generating mechanism by YS11, deamination of amino acids is highly speculated as strain YS11 pertains to deamination pathways, contributing to its alkali generating characteristic.

\section{Co-occurrence alters the appearance of calcium carbonate precipitation}

After monitoring the growth, $\mathrm{pH}$ change, and calcium ion concentration, cultured cells were visualized for precipitated calcium carbonate minerals. It has been characterized that $L$. boronitolerans YS11 precipitates calcium carbonate when calcium source is provided in the medium (Lee et al. 2017). Resultant calcium carbonate was confirmed from both YS11 culture alone and YS11 plus AK13 coculture condition (Fig. 4a, b). MICP induced by YS11 in YL medium resulted in round shaped mineral aggregates whereas MICP induced by mixed culture depicted smaller particle size and more compact form (Fig. 4a). Besides such difference in mineral shape, the coculture showed distinct formation of EPSs within calcium carbonate-cell clusters (Fig. 4a). Minerals precipitated in both cultures were verified to be calcium carbonates as the FTIR analysis showed three peaks of samples identical to reference calcium carbonate peaks (Fig. 4b).

To verify relations between EPSs and calcium carbonate generation, cells were incubated in static condition for biofilm and calcium carbonate development periodically. Image analysis by CLSM showed similar results (Fig. 4c). Both YS11 single culture and YS11 plus AK13 coculture were in developmental stage of biofilm in $24 \mathrm{~h}$, matured biofilm in $48 \mathrm{~h}$, and dispersed form in $72 \mathrm{~h}$. In all stages, biofilm formed under YS11 plus AK13 coculture condition was much higher (Fig. 4c). Along with biofilm 
Table 3 Genes involved in production of ammonia and deamination of amino acids

\begin{tabular}{|c|c|c|c|}
\hline Coordinates & Strand & Product & Gene name \\
\hline $266,921-268,435$ & + & Histidine ammonia-lyase & hutH \\
\hline $318,892-320,310$ & - & Putative amidase AmiD & \\
\hline $435,365-436,537$ & + & Lysine 6-dehydrogenase & \\
\hline $535,842-537104$ & - & Phenylserine dehydratase & \\
\hline $1,039,715-1,040,377$ & + & Probable L-serine dehydratase, beta chain & $s d a A B$ \\
\hline $1,040,392-1,041,300$ & + & Probable L-serine dehydratase, alpha chain & sdaAA \\
\hline $1,101,650-1,102,153$ & + & Probable chemoreceptor glutamine deamidase CheD 1 & \\
\hline $1,318,421-1,319,788$ & - & Guanine deaminase & guad \\
\hline $1,430,688-1,431,656$ & - & L-Asparaginase & \\
\hline $1,547,319-1,548,554$ & + & Allantoate deiminase & \\
\hline $1,581,552-1,582,922$ & + & Ethanolamine ammonia-lyase heavy chain & \\
\hline $1,582,932-1,583,942$ & + & Ethanolamine ammonia-lyase light chain & \\
\hline $1,614,306-1,615,679$ & - & NADP-specific glutamate dehydrogenase & \\
\hline $1,616,318-1,617,646$ & + & Probable D-serine dehydratase & \\
\hline $1,804,351-1,805,055$ & + & Glucosamine-6-phosphate deaminase & \\
\hline $1852010-1852543$ & + & Peroxyureidoacrylate/ureidoacrylate amidohydrolase RutB & \\
\hline $2,097,252-2,098,670$ & + & Aspartate ammonia-lyase & aspa \\
\hline $2,100,543-2,100,845$ & + & Urease subunit gamma & ureA \\
\hline $2,100,861-2,101,229$ & + & Urease subunit beta & \\
\hline $2,101,226-2,102,941$ & + & Urease subunit alpha & urec \\
\hline $2,423,272-2,424,252$ & - & Meso-diaminopimelate $\mathrm{D}$-dehydrogenase & \\
\hline $2,687,063-2,688,808$ & - & Adenine deaminase & ade \\
\hline $2,743,214-2,744,329$ & + & Cystathionine beta-lyase MetC & \\
\hline $2,850,380-2,851,474$ & - & Leucine dehydrogenase & \\
\hline $2,897,281-2,898,246$ & - & Glutaminase 1 & $g \mid s A$ \\
\hline $2,913,990-2,915,093$ & - & Aminomethyltransferase & gcvT \\
\hline $3,177,391-3,178,323$ & - & Porphobilinogen deaminase & \\
\hline $3,406,895-3,408,010$ & - & Alanine dehydrogenase & ald \\
\hline $3,539,367-3,540,581$ & - & Diaminopropionate ammonia-lyase & \\
\hline $3,564,845-3,566,089$ & - & Catabolic NAD-specific glutamate dehydrogenase RocG & \\
\hline $3,575,261-3,576,433$ & + & Cystathionine beta-lyase PatB & \\
\hline $3,688,923-3,690,383$ & - & Putative amidase AmiC & \\
\hline $3,856,477-3,857,190$ & - & Glucosamine-6-phosphate deaminase & $\operatorname{nag} B$ \\
\hline $3,991,464-3,993,185$ & - & Putative adenine deaminase PTO1085 & \\
\hline $4,002,226-4,002,909$ & - & Phosphoribosylformylglycinamidine synthase subunit PurQ & \\
\hline
\end{tabular}

formation, much more biofilm bound calcium carbonate was observed in the coculture (Fig. 4c). Quantification of biofilm formation was performed after crystal violet staining to examine equivalent results as CLSM images. Accordingly, biofilm formation in coculture was measured to be 1.5-fold higher than that in YS11 single culture (Fig. 4d). Enhanced biofilm formation in coculture by strain AK13 might give nucleation site for calcium carbonate, suggesting more surface-calcium carbonate bound cells.

Survival of YS11 in sole culture and coculture were compared under alkaline $\mathrm{pH}$ of 12 . The survival of
YS11 from the coculture was improved (Fig. 4e). This suggests that altered EPS composition and quantity of biofilm formation might have contributed to the improvement in the survival of YS11 when it is cocultured with AK13. CCP bacteria are often applied inside building materials such as concrete for repairment of crack initiations (Lee and Park 2018). Because the $\mathrm{pH}$ of the concrete matrix is up to 13 , our result suggests that increased survival from the co-occurrence of YS11 and AK13 could also show enhanced healing rate of cracks when applied into cementitious materials. 

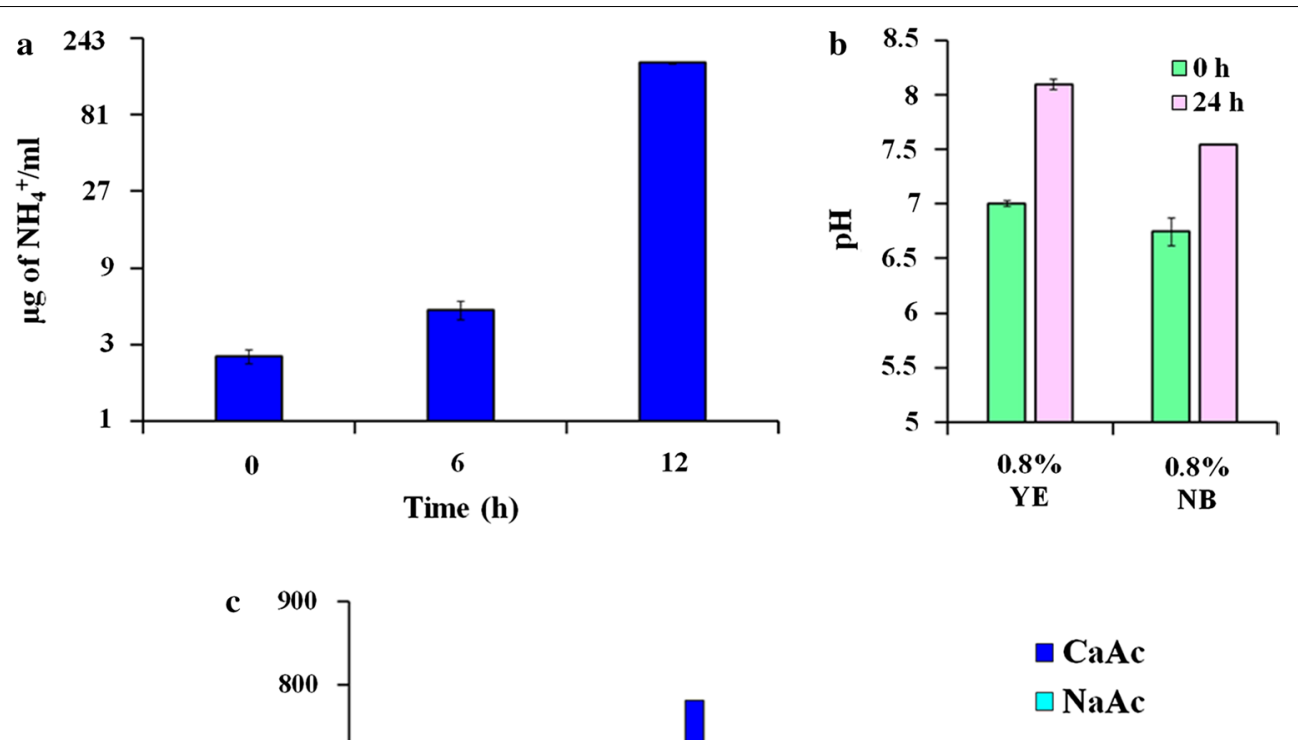

Fig. 2 a Quantification of ammonia production from supernatant of YS11 cultured in YL medium. $\mathbf{b}$ pH increases by YS11 in amino acid rich media ( $.8 \%$ yeast extract or $.8 \%$ nutrient broth). $\mathbf{c}$ Expression of ammonia releasing genes from YS11 that exhibited RPKM value higher than 100 

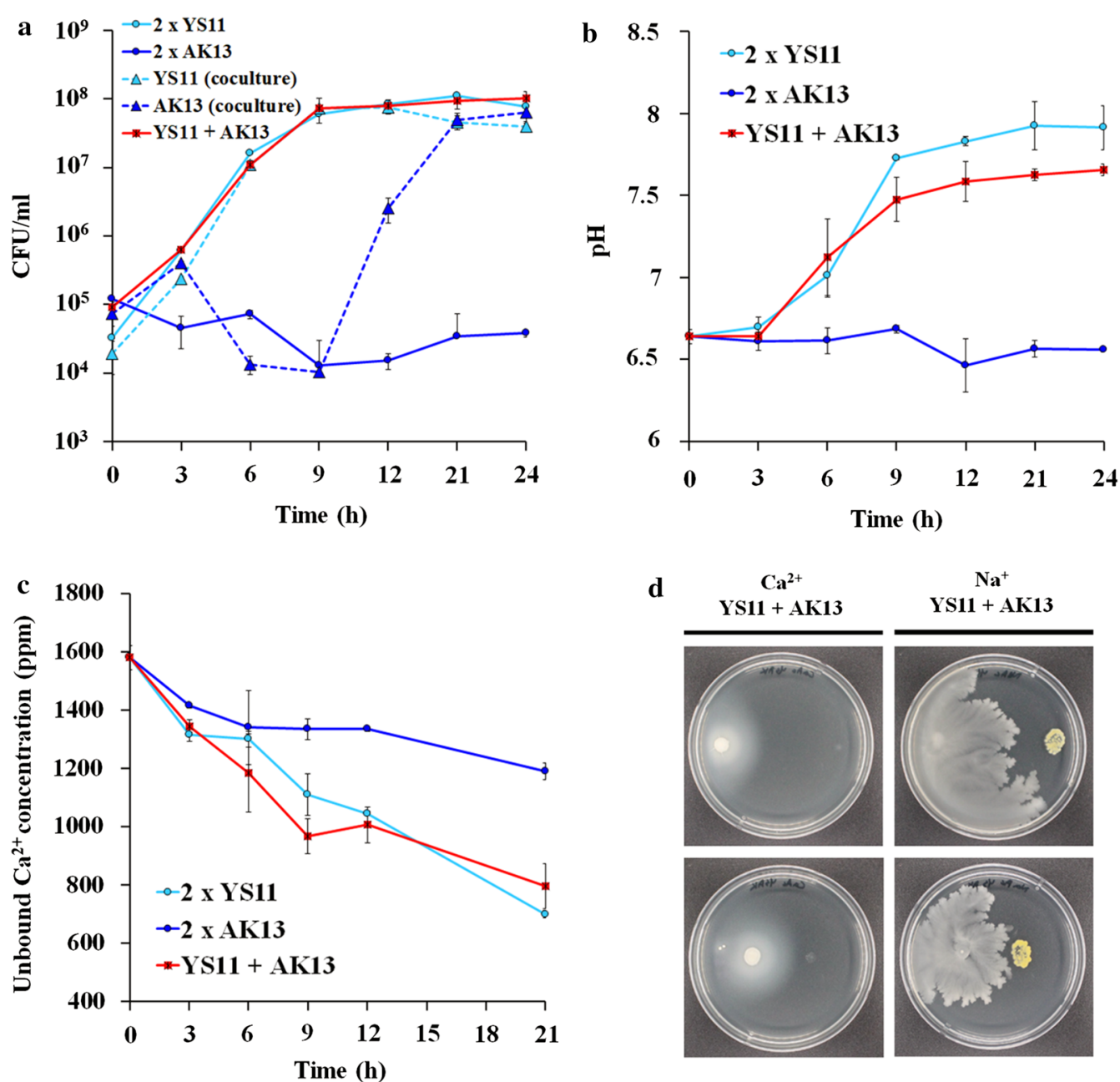

d

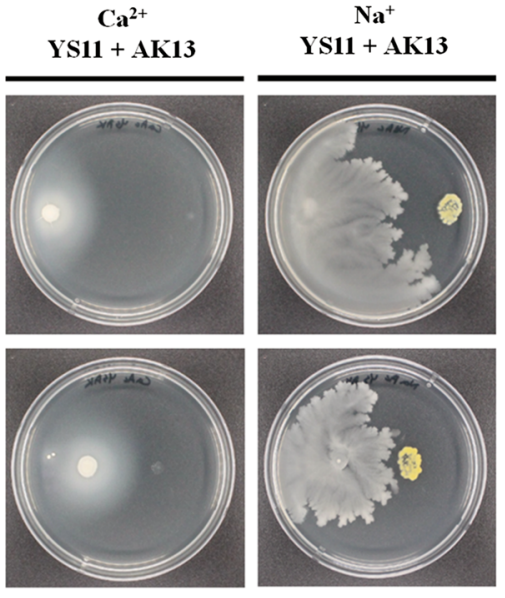

Fig. 3 Growth, pH changes, and calcium utilization in MICP-inducing conditions with YS11, AK13 alone, and YS11 + AK13 coculture. a Based on CFU growth of YS11, AK13, and YS11 + AK13, the growth of AK13 is facilitated by coculture with YS11. b pH changes in YS11, AK13 single culture, and YS11 + AK13 coculture are shown. $\mathbf{c}$ Unbound $\mathrm{Ca}^{2+}$ concentrations in supernatants of YS11, AK13 single culture, and YS11+AK13 coculture are measured. $\mathbf{d}$ Induced growth of AK13 from coculture with YS11 in agar plate cultures

\section{Modification of membrane rigidity during calcium carbonate precipitation}

The growth curve of YS11 in CaAc medium and NaAc medium showed similar growth rates (Fig. 5a). To determine changes in physiology of YS11 during calcium carbonate precipitation when $\mathrm{Ca}^{2+}$ was near, RNA-seq was conducted for mid-exponentially grown cells from both NaAc and CaAc conditions (Table 4). Interestingly, upregulation of branched chain amino acid (BCAA) and branched chain fatty acid (BCFA) synthesis was noticeable in transcriptomics of calcium carbonate precipitation (CaAc medium) compared to that of the control (NaAc medium). YS11 retained all genes involved in both BCAA and BCFA synthesis in one operon (Fig. 5b). BCAA synthesis pathway is directly connected to BCFA pathway where BCFA are produced as cellular components
(Fig. 5b). Furthermore, genes involving multi-drug efflux pump, membrane protein related genes, and membrane protease-involved genes were also upregulated when $\mathrm{Ca}^{2+}$ was provided (at CaAc condition) (Table 4). These results suggest modification of membrane during MICP. Thus, fatty acid methyl esters (FAMEs) of YS11 from $\mathrm{NaAc}$ and $\mathrm{CaAc}$ cultures were quantified to determine any modification in BCFA composition. Noticeably higher value in total BCFA ratio including anteiso BCFA and iso BCFA ratios were measured under $\mathrm{CaAc}$ condition compared to that under $\mathrm{NaAc}$ condition after $12 \mathrm{~h}$ of culture (Fig. 5c). This result demonstrates alteration in phenotype of membrane rigidity from the presence of $\mathrm{Ca}^{2+}$. However, the BCFA ratio in $6 \mathrm{~h} \mathrm{CaAc}$ condition was unsubstantial compared to that in $6 \mathrm{~h} \mathrm{NaAc}$ condition. Although gene expression at $\mathrm{CaAc}$ condition 
a
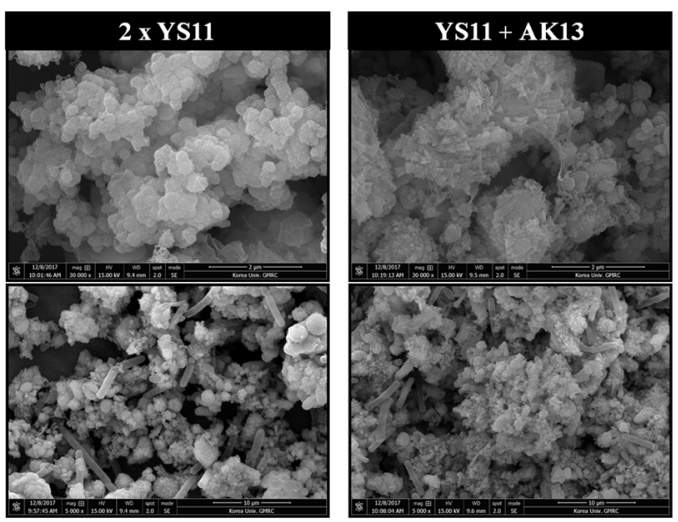

$\mathbf{c}$
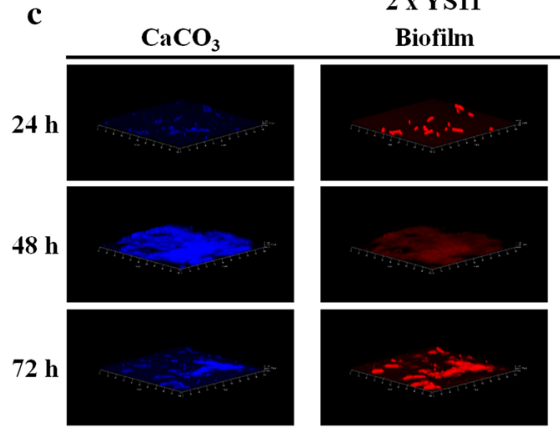

YS11 + AK13

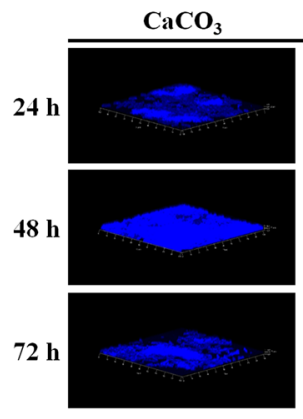

Biofilm

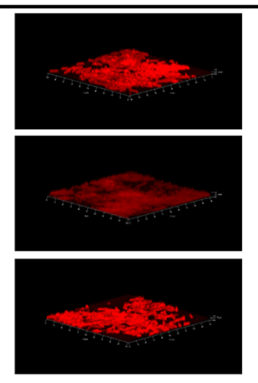

Merge

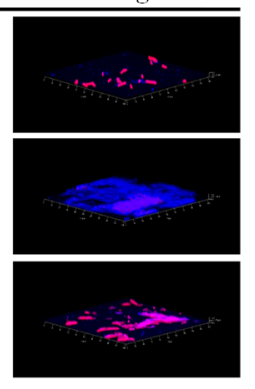

Merge

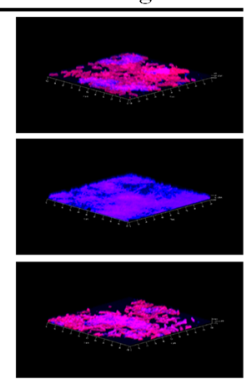

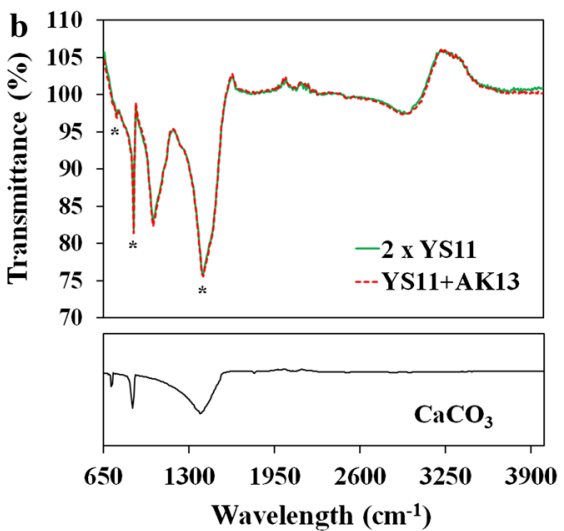
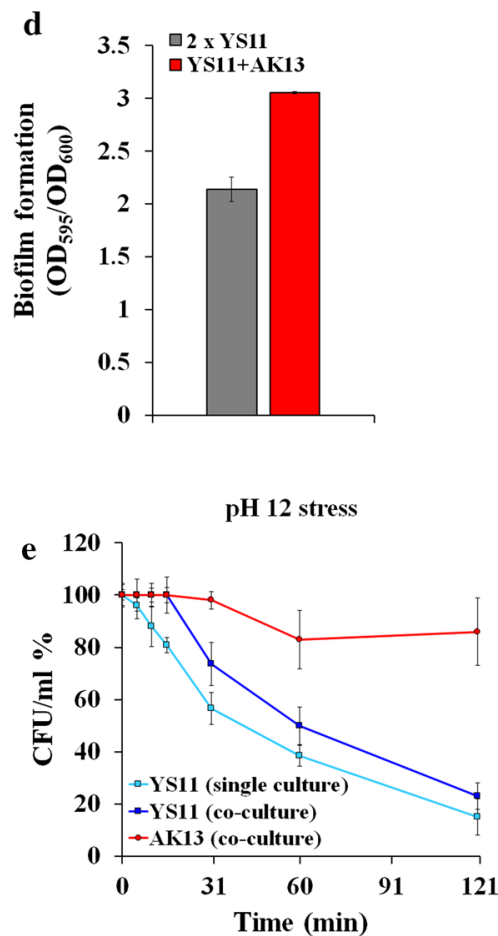

Fig. 4 a Field emission scanning electron microscopy (FE-SEM) of calcium carbonate precipitated by YS11 single culture and YS11+AK13 coculture ( $\times 30,000$ and ×5000 magnification). b FTIR analysis of precipitated calcium carbonate. c CLSM image of biofilm and calcium carbonate produced by YS11 single culture. $\mathbf{d}$ Crystal violet quantification of biofilm formation in single culture or YS11 + AK13 coculture. e Killing curve assay of YS11 alone, AK13 alone, and YS11 plus AK13 under pH 12

showed considerable difference compared to that at $\mathrm{NaAc}$ condition at $6 \mathrm{~h}$, protein difference and phenotypical changes were only evident from $12 \mathrm{~h}$. For the first time, we show genomic and phenotypic characteristics of $\mathrm{CCP}$ bacteria during $\mathrm{CaCO}_{3}$ precipitation through differential gene expression and FAME analyses. It was questionable whether calcium carbonate crystals were present during $6 \mathrm{~h}$ incubation where major transcriptomic changes were observed. FE-SEM and EDS obtained after $6 \mathrm{~h}$ of incubation in CaAc medium confirmed the presence of calcium carbonate (Additional file 1: Fig. S3). Presence of $\mathrm{Ca}^{2+}$ also affects phenotypes of Lysinibacillus boronitolerans YS11. Spore formation and biofilm formation were all increased in CaAc compared to those in NaAc (Figs. 6a, b). The increase of biofilm formation in CaAc was also observed in CLSM image where the glass surface was covered up by biofilms under $\mathrm{CaAc}$ condition compared to scattered biofilm under $\mathrm{NaAc}$ condition (Fig. 6c). Swimming motility was also measured under $\mathrm{CaAc}$ and $\mathrm{NaAc}$ conditions. Swimming of 


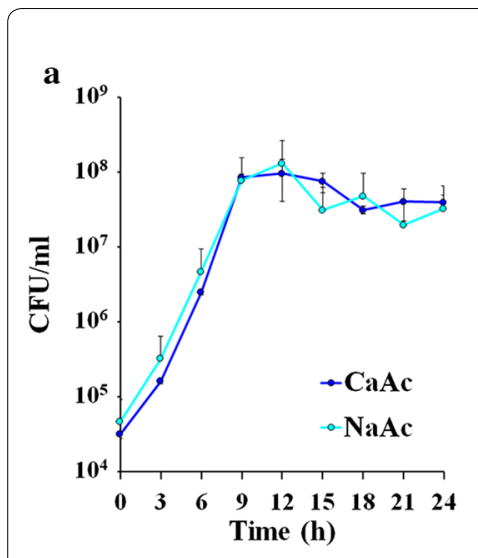

b
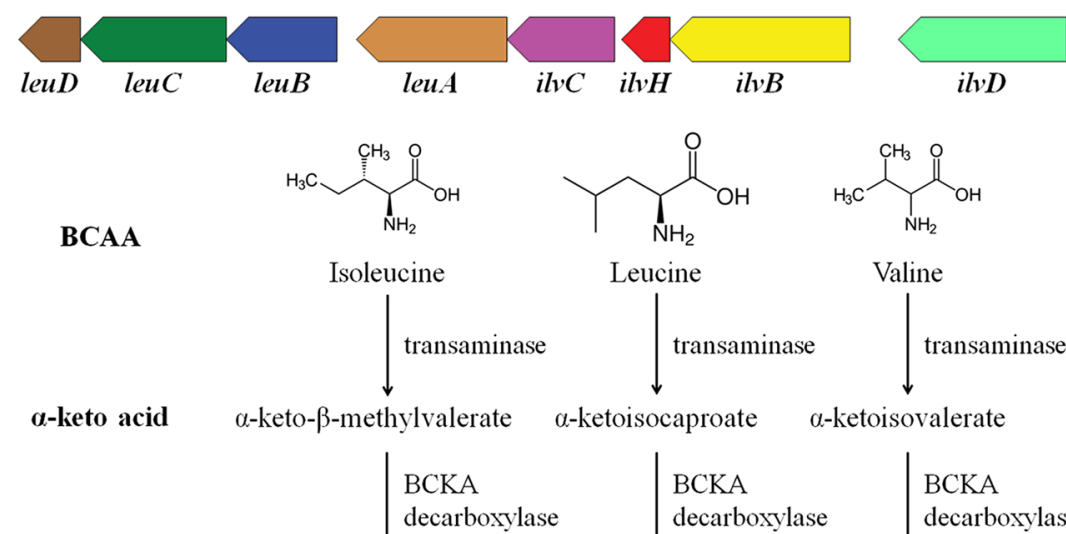

CoA ester

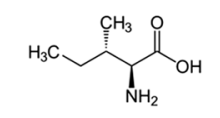

$$
\text { Isoleucine }
$$

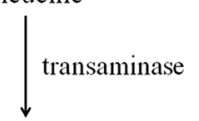

$\alpha$-keto- $\beta$-methylvalerate

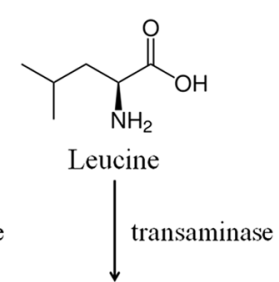<smiles>CC(C)C(C)C(C)O</smiles>

Valine

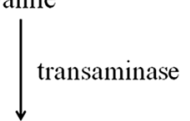

$\alpha$-ketoisocaproate

a-ketoisovalerate

$$
\downarrow \begin{aligned}
& \text { BCKA } \\
& \text { decarboxylase }
\end{aligned}
$$$$
\downarrow \begin{array}{l|l}
\text { BCKA } & \begin{array}{l}
\text { BCKA } \\
\text { decarboxylase }
\end{array}
\end{array}
$$

2-methylbutyryl-CoA

Isovaleryl CoA

Isobutyryl CoA

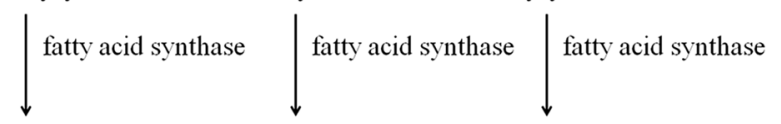

BCFA
Iso-fatty acids

Iso-fatty acids
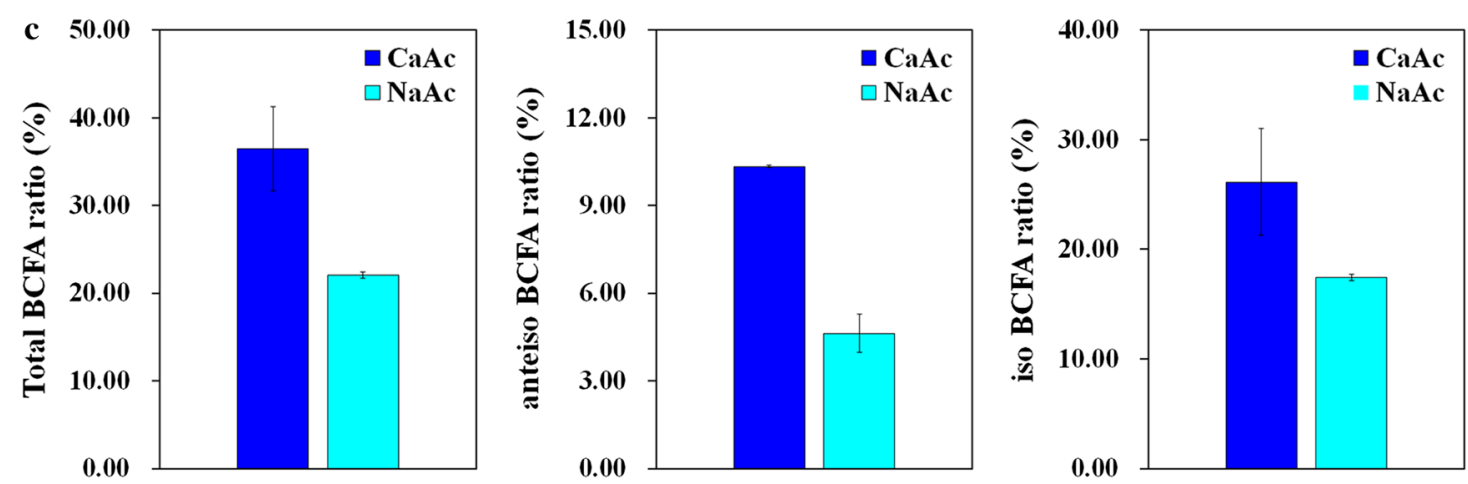

Fig. 5 a Growth curve of YS11 in calcium-rich condition (CaAc) and calcium-poor condition (NaAc). b Schematic view of upregulated branched chain amino acid (BCAA) and branched chain fatty acid (BCFA) synthesis in CaAc. c Modified BCFA ratio in CaAc compared to that in NaAc

YS11 in $\mathrm{Ca}^{2+}$-rich condition was much higher than that under $\mathrm{NaAc}$ condition. It covered all area of the petri dish (Fig. 6d). $\mathrm{Ca}^{2+}$-specific differences in various phenotypes demonstrate that strain YS11 shows responses corresponding to $\mathrm{Ca}^{2+}$. Further experiments are needed to determine the mechanisms underlying these differences.

\section{Discussion}

CCP bacteria prevail in the environment. However, their ecological interactions between species remain to be examined in detail. Complete genome analysis for strain YS11 was performed. Through average nucleotide identity (ANI) analysis, this species belonged to $L$. boronitolerans. Upregulation of deaminase activities in $\mathrm{pH}$ increasing conditions from RNA-seq and ammonia production support that deamination of amino acids was a factor involved in alkaline generation by YS11. In oral cavity, alkaline generating pathways have been proposed to be arginine deaminase system or arginine decarboxylated agmatine deaminase system together with urea hydrolyses (Liu et al. 2012). To explore interspecies interaction of this alkaline generating strain YS11, isolation of additional bacteria was proceeded from the isolation spot of strain YS11 to identify bacteria in cooccurrence with YS11. Interestingly, an alkaliphilic bacterium Bacillus sp. AK13 whose growth was inhibited in neutral condition was isolated from the identical spot where neutrophilic strain YS11 was isolated. YS11 was able to facilitate the growth of AK13 by alkalization of neutral environment when they were cocultured. It is interesting to note that these two species that co-occur at the same habitat show very different degrees of optimal growth dependent on $\mathrm{pH}$. Coculture of the two species promoted increased MICP within biofilm matrix. Structure analysis and 
Table 4 Upregulated and downregulated genes in $\mathrm{CaAc}$ and $\mathrm{NaAc}$ condition (gene expression $\geq 100$, fold change $\geq 2$, and $p$ value $\leq .05$ )

\begin{tabular}{|c|c|c|c|c|c|c|}
\hline Locus taq & Gene symbol & Product & Strand & CaAc RPKM & NaAc RPKM & $\mathrm{CaAc} / \mathrm{NaAc}$ \\
\hline \multicolumn{7}{|c|}{ Genes upregulated by high $\mathrm{Ca}^{2+}$} \\
\hline \multicolumn{7}{|c|}{ Branched chain amino acid synthesis } \\
\hline LBYS11_13585 & & Acetolactate synthase small subunit & - & 144.04 & 14 & 10.29 \\
\hline LBYS11_13570 & leuB & 3-Isopropylmalate dehydrogenase & - & 124.41 & 12.67 & 9.82 \\
\hline LBYS11_13580 & & Ketol-acid reductoisomerase & - & 263.2 & 27.42 & 9.6 \\
\hline LBYS11_13560 & leuD & 3-Isopropylmalate dehydratase small subunit & - & 116.42 & 12.75 & 9.13 \\
\hline LBYS11_13565 & leuC & 3-Isopropylmalate dehydratase large subunit & - & 144.46 & 17.55 & 8.23 \\
\hline LBYS11_13575 & & 2-Isopropylmalate synthase & - & 165.84 & 20.78 & 7.98 \\
\hline LBYS11_13590 & $i l v B$ & Acetolactate synthase large subunit IlvB1 & - & 131.49 & 18.13 & 7.25 \\
\hline LBYS11_13595 & $i / v D$ & Dihydroxy-acid dehydratase & - & 223.6 & 41.14 & 5.44 \\
\hline \multicolumn{7}{|c|}{ Branched chain fatty acid synthesis } \\
\hline LBYS11_00205 & & $\begin{array}{l}\text { Hypothetical protein (NCBI blast: 3-oxoacyl-(Acyl-carrier- } \\
\text { protein (ACP)) synthase III) }\end{array}$ & + & 1150.45 & 113.55 & 10.13 \\
\hline LBYS11_00220 & & Phosphopantetheine-binding protein & + & 1044.75 & 125.49 & 8.33 \\
\hline LBYS11_00200 & & Hypothetical protein: holo-[acyl-carrier-protein] synthase & + & 956.13 & 115.3 & 8.29 \\
\hline LBYS11_00230 & & Hypothetical protein: holo-[acyl-carrier-protein] synthase & + & 1028.85 & 125.53 & 8.2 \\
\hline \multicolumn{7}{|l|}{ Lysine synthesis } \\
\hline LBYS11_00215 & IysA & Diaminopimelate decarboxylase & + & 1089.26 & 118.57 & 9.19 \\
\hline \multicolumn{7}{|c|}{ Might serve as radioprotective agent } \\
\hline LBYS11_06125 & & Glutathionylspermidine synthase & + & 315.38 & 82.76 & 3.81 \\
\hline \multicolumn{7}{|c|}{ Protease involved genes } \\
\hline LBYS11_00265 & & Uncharacterized zinc protease YmfH & + & 754.93 & 96.72 & 7.81 \\
\hline LBYS11_00260 & & Zinc protease & + & 685.49 & 90.94 & 7.54 \\
\hline LBYS11_06700 & & n|Uncharacterized protein YuaG & + & 560.04 & 124.56 & 4.5 \\
\hline LBYS11_16935 & hflk & FtsH protease activity modulator $\mathrm{HflK} \mid$ Protein $\mathrm{HflK}$ & - & 605.83 & 146.1 & 4.15 \\
\hline LBYS11_16930 & $h f l C$ & Protease modulator $\mathrm{HflC}$ Protein $\mathrm{HflC}$ & - & 887.2 & 231.43 & 3.83 \\
\hline LBYS11_17070 & sppA & $\begin{array}{l}\text { Signal peptide peptidase SppA|Putative signal peptide pepti- } \\
\text { dase SppA }\end{array}$ & - & 139.57 & 36.6 & 3.81 \\
\hline \multicolumn{7}{|c|}{ Multidrug efflux pump and swarming motility involved genes } \\
\hline LBYS11_00190 & & $\begin{array}{l}\text { Multidrug export protein AcrF Cobalt-zinc-cadmium resist- } \\
\text { ance protein CzCA }\end{array}$ & + & 336.58 & 42.35 & 7.95 \\
\hline LBYS11_00195 & & Swarming motility protein SwrC & + & 800.18 & 106.83 & 7.49 \\
\hline LBYS11_00255 & & $\begin{array}{l}\text { Hypothetical protein Multi antimicrobial extrusion protein } \\
(\mathrm{Na}(+) / \text { drug antiporter })\end{array}$ & + & 376.26 & 51.85 & 7.26 \\
\hline LBYS11_00250 & & $\begin{array}{l}\text { Hypothetical protein Multi antimicrobial extrusion protein } \\
(\mathrm{Na}(+) / \text { drug antiporter })\end{array}$ & + & 265.05 & 37.79 & 7.01 \\
\hline \multicolumn{7}{|c|}{ TCA cycle involved genes } \\
\hline LBYS11_00240 & & Acyl-CoA dehydrogenase & + & 1676.26 & 217.77 & 7.7 \\
\hline LBYS11_07645 & & NADP-specific glutamate dehydrogenase & - & 453.98 & 112.24 & 4.04 \\
\hline \multicolumn{7}{|l|}{ Hydantoinase } \\
\hline LBYS11_08510 & & $N$-methyl hydantoinase & + & 162.46 & 21.19 & 7.67 \\
\hline LBYS11_08515 & & Hydantoinase subunit beta & + & 225.3 & 32.87 & 6.85 \\
\hline \multicolumn{7}{|c|}{ Membrane proteins } \\
\hline LBYS11_13515 & & Uncharacterized membrane protein YceF & + & 664.23 & 68.7 & 9.67 \\
\hline LBYS11_06695 & & Uncharacterized membrane protein YuaF & + & 432.69 & 89.78 & 4.82 \\
\hline LBYS11_17065 & & RDD family protein|Uncharacterized membrane protein YteJ & - & 362.02 & 93.05 & 3.89 \\
\hline LBYS11_20665 & & Hypothetical protein|UPF0699 transmembrane protein YdbS & - & 148.94 & 39.48 & 3.77 \\
\hline \multicolumn{7}{|c|}{ Hypothetical proteins } \\
\hline LBYS11_00210 & & Hypothetical protein & + & 1190.22 & 124.33 & 9.57 \\
\hline LBYS11_00225 & & Hypothetical protein & + & 1021.86 & 116.54 & 8.77 \\
\hline
\end{tabular}


Table 4 (continued)

\begin{tabular}{|c|c|c|c|c|c|c|}
\hline Locus taq & Gene symbol & Product & Strand & CaAc RPKM & NaAc RPKM & $\mathrm{CaAc} / \mathrm{NaAc}$ \\
\hline LBYS11_00235 & & Hypothetical protein & + & 1193.34 & 140.21 & 8.51 \\
\hline LBYS11_00245 & & Hypothetical protein & + & 1002.8 & 129.52 & 7.74 \\
\hline LBYS11_09000 & & Hypothetical protein & + & 232.67 & 38.56 & 6.03 \\
\hline LBYS11_09005 & & Hypothetical protein & + & 186.62 & 33.96 & 5.5 \\
\hline LBYS11_09815 & & Hypothetical protein & + & 153.15 & 32.91 & 4.65 \\
\hline LBYS11_21200 & & Hypothetical protein & - & 143.8 & 32.67 & 4.4 \\
\hline LBYS11_19760 & & Hypothetical protein|Uncharacterized protein YvIA & + & 133.72 & 33.88 & 3.95 \\
\hline LBYS11_06120 & & $\begin{array}{l}\text { Hypothetical protein|Uncharacterized serine-rich protein } \\
\text { C21513 }\end{array}$ & + & 413.46 & 112.58 & 3.67 \\
\hline \multicolumn{7}{|c|}{ Genes downregulated by high $\mathrm{Ca}^{2+}$} \\
\hline LBYS11_19235 & & Copper amine oxidase & - & 63.11 & 224.53 & .28 \\
\hline LBYS11_08750 & & Copper amine oxidase & + & 52.07 & 239.12 & .22 \\
\hline LBYS11_20870 & & Zinc transporter ZupT & - & 133.27 & 521.26 & .26 \\
\hline LBYS11_01430 & & Divalent metal cation transporter & - & 8.88 & 211.74 & .04 \\
\hline LBYS11_20140 & & Guanine/hypoxanthine permease & - & 9.31 & 157.38 & .06 \\
\hline
\end{tabular}

quantification of biofilm and calcium carbonate also suggested that growths of both bacteria were enhanced in coculture condition. Our result of one alkali generating species enabling the survival of another alkaliphilic species suggests that species possessing ecologically different niches contributing to diverse environmental parameters can co-occur in same habitat by induction of an adequate environment by the other species. A recent study has investigated interspecies interaction among Lysinibacillus fusiformis M5 and Bacillus subtilis 168 (GallegosMonterrosa et al. 2017). It was found that hypoxanthine released from $L$. fusiformis induced architectural changes in biofilm of B. subtilis, thus altering wrinkle formation. Furthermore, transcriptomics under $\mathrm{Ca}^{2+}$ poor and $\mathrm{Ca}^{2+}$ rich conditions were conducted as to understand genetic characteristics and differential gene expressions during $\mathrm{CaCO}_{3}$ precipitation. Under $\mathrm{Ca}^{2+}$ rich condition, genes involved in branched chain amino acid and branched chain fatty acid syntheses were highly upregulated, including multi-drug efflux pump and membrane protein related genes, suggesting modification in membrane during $\mathrm{Ca}^{2+}$ contact. Various phenotypes (growth, biofilm formation, sporulation, swimming motility, and stress response) were altered under $\mathrm{Ca}^{2+}$ rich condition. Our study demonstrates that $\mathrm{pH}$ increase of $L$. boronitolerans YS11 enables the growth of Bacillus sp. AK13 dwelling in the same environmental niche. Such dual species interaction in the environment shapes CCP characteristics and leads to higher biofilm formation.

In this study, the interaction between two environmental isolates, alkali generating CCP bacteria Lysinibacillus boronitolerans YS11 and alkalitolerant Bacillus sp. AK13, dwelling at same location was examined. While neutral environment was a barrier for the growth of Bacillus sp. AK13, alkalization provided by L. boronitolerans YS11 enabled adequate living condition for AK13. Alkaline generation by bacteria has been observed many times. Recently alkaline generating pathways in oral bacteria have been identified through meta-omics approach (Edlund et al. 2015). According to that study, major $\mathrm{pH}$ increasing pathways for oral bacterial microbiome include the following: (1) arginine deaminase system, (2) urea transport and urease activity, (3) glutamate transport and glutamate dehydrogenase activity, (4) threonine deaminase activity, and (5) serine deaminase activity. Complete genome sequence of strain YS11 was obtained in this study to identify alkaline generation pathway leading to MICP. Strain YS11 contained many genes involved in deamination of amino acids (Table 3). Ammonia measurement in YL medium showed an increase in ammonia production, suggesting that strain YS11 could utilize amino acids provided by amino acid rich yeast extract (Fig. 2a, b). Transcriptomic analysis from RNA-seq at $\mathrm{CaAc}$ and $\mathrm{NaAc}$ conditions support that genes involved in deamination were expressed during $\mathrm{pH}$ increase in this complex media (Fig. 2c). Ammonia production from other amino acids deamination pathways, including glutamate dehydrogenase, arginine deaminase, and threonine deaminase, is highly possible based on genomic analysis of YS11 (Table 3). Co-occurrence of strain YS11 and alkaliphilic AK13 was thus enabled through deamination activities of YS11. The morphology of calcium carbonate produced from mixed culture was altered into compact shape and biofilm attached calcium carbonate production was higher from SEM and CLSM analyses (Fig. 4a, c). Co-occurrence of these two species also 

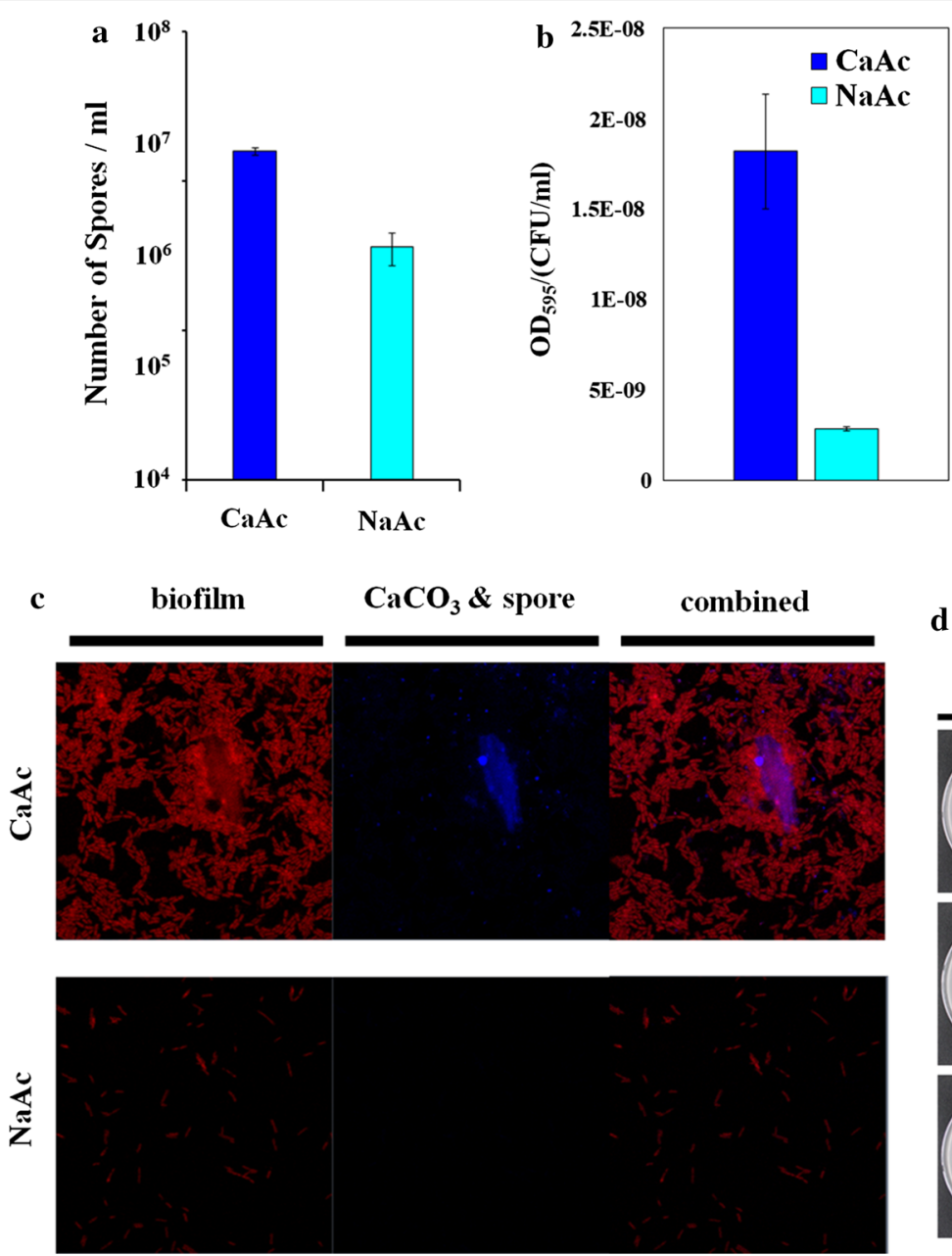

d Swimming assay with $0.25 \%$ agar
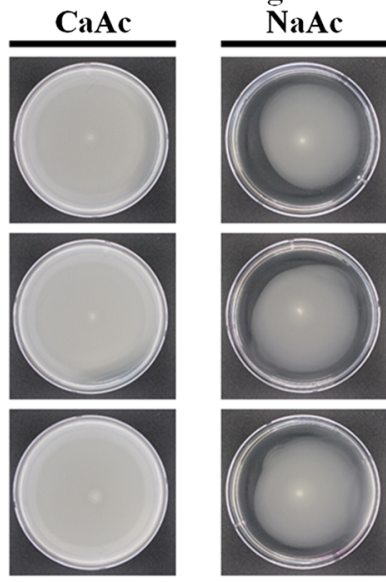

Fig. 6 a Enhanced spore formation of YS11 in calcium-rich condition. b Increased biofilm formation in calcium-rich condition. c CSLM image of increased biofilm (red) formation in calcium-rich condition (blue color indicates calcium carbonate mineral). $\mathbf{d}$ Increase in swimming motility in calcium-rich condition compared to that in calcium-poor condition

enhanced biofilm formation compared to single YS11 culture. These results suggest that alteration of EPSs components from dual species interaction can lead to formation of morphologically different calcium carbonate in coculture compared to single culture. Interestingly, AK13 in the biofilm only comprised of .05\% whereas its biomass in agitation planktonic culture was $60 \%$ (data not shown). The phenotypic change in biofilm formation was significant even in miniscule population and the production of biofilm attached calcium carbonates increased accordingly (Fig. 3). Coculture with AK13 in return enhanced $\mathrm{pH}$ susceptibility of YS11. Strain YS11 was able to survive better when it was co-occurred with strain AK13 (Fig. 4d). These results demonstrate that bacteria having different physiological characteristics such as alkali generating feature and alkaliphilic feature can dwell collaboratively in nature and affect mineral formation and cell-surface attachment in nature. Ecological characteristics of alkali generating CCP bacteria in a par with an alkaliphilic bacteria were observed in this study. Nucleation effect of bacterial EPS has been accepted as a notion for bacterial MICP (Dupraz et al. 2009; Tourney and Ngwenya 2009; Zhu and Dittrich 2016). One study has explored interspecies interaction between Lysinibacillus species and Bacillus species and found that soil bacteria L. fusiformis can induce architectural changes in biofilm colonies when it is cocultured with Bacillus subtilis (Bilecen and Yildiz 2009). EPSs (exopolysaccharides) are crucial in shaping the morphology of calcium carbonate and its quantity because they lender nucleation sites for mineral precipitation. Thus, the property of EPSs holds great potential for calcium carbonate precipitation (Dupraz et al. 2009). To test surface chemical properties and attachment ability, EPS components should be analyzed. 
Researches in biofilm have evolved to show major interest in microbiology recently. Because of the innate characteristic of biofilm as a sanctuary in various environmental conditions, biofilm possesses social interactions for multiple microbial populations, ranging from a single, a pair, to multispecies communities (Knoll 2003). These interactions between microorganisms forming a biofilm play a substantial role in this research field. They shape the development of these communities, make the community complex by intraspecies signaling, interspecies communications, or chemical cues derived from the metabolism of certain community members. It was $\mathrm{pH}$ signaling in this paper. Here, we demonstrate that interaction of two environmental bacterial interspecies in biofilm further influences mineral precipitation patterns on Earth surface. Further study on mixed culture MICP of biofilms will lead to improved understanding of biogenic carbonate precipitation in nature.

\section{Additional file}

Additional file 1: Fig. S1. (A) Presence absence gene analysis of YS11 with other Lysinibacillus species including L. boronitolerans NBRC 103108', L. macroides DSM 54 ${ }^{\top}$, L. xylanilyticus DSM 23493', and L. pakistanensis JCM $18776^{\top}$. (B) COG category of Lysinibacillus species. Fig. S2. (A) Phylogenetic neighbor joining tree of strain AK13. (B) pH dependent growth of alkalifying strain YS11 and alkaliphilic strain AK13. Fig. S3. FE-SEM and EDX analyses for nanoparticle calcium carbonate formed during early growth (6 h).

\section{Abbreviations \\ L. boronitolerans: Lysinibacillus boronitolerans; MICP: microbially induced calcium carbonate; $\mathrm{CCP}: \mathrm{CaCO}_{3}$ precipitating; EPS: exopolysaccharide; LB: Luria-Bertani; PBS: phosphate buffered saline; CaAc: calcium acetate; NaAc: sodium acetate; CFU: colony-forming unit; RPKM: reads per kilobase of the exon sequence per million mapped sequence reads; OD: optical density; FE-SEM: field emission scanning electron microscopy; FTIR: Fourier-transform infrared spectroscopy; MSB: minimal salt medium; CLSM: confocal laser scan- ning microscopy; FAME: fatty acid methyl esters; EDS: energy dispersive X-ray spectrometer; ANI: average nucleotide identity.}

\section{Authors' contributions}

YSL and WP designed this study. YSL performed experiments. YSL analyzed data. YSL drafted the manuscript. YSL and WP participated substantially in discussion and manuscript modifications. Both authors contributed to this manuscript. Both authors read and approved the final manuscript.

\section{Acknowledgements}

Not applicable.

\section{Competing interests}

The authors declare that they have no competing interests.

\section{Availability of data and materials}

The complete genome sequence of Lysinibacillus boronitolerans YS11 has been deposited in NCBI under the GenBank accession number CP026007.1. The RNA-seq of Lysinibacillus boronitolerans YS11 has been deposited in NCBI under the SRA number SRR8083459. YS11 and AK13 strains were deposited in the KACC (accession numbers KACC81048BP and KACC81070BP, respectively).
Consent for publication Not applicable.

Ethics approval and consent to participate

Not applicable.

\section{Funding}

This research was supported by a grant (19SCIP-B103706-05) from Construction Technology Research Program funded by the Ministry of Land, Infrastructure and Transport, Republic of Korea.

\section{Publisher's Note}

Springer Nature remains neutral with regard to jurisdictional claims in published maps and institutional affiliations.

Received: 28 March 2019 Accepted: 2 April 2019

Published online: 11 April 2019

\section{References}

Andrews SC, Robinson AK, Rodriguez-Quinones F (2003) Bacterial iron homeostasis. FEMS Microbiol Rev 27:215-237

Arp G, Reimer A, Reltner J (2001) Photosynthesis-induced biofilm calcification and calcium concentrations in Phanerozoic oceans. Science 292:1701-1704

Bai Y, Guo XJ, Li YZ, Huang T (2017) Experimental and visual research on the microbial induced carbonate precipitation by Pseudomonas aeruginosa. AMB Express 7:57

Bertrand JJ, West JT, Engel JN (2010) Genetic analysis of the regulation of type IV pilus function by the Chp chemosensory system of Pseudomonas aeruginosa. J Bacteriol 192:994-1010

Bhaskar PV, Bhosle NB (2006) Bacterial extracellular polymeric substance (EPS): a carrier of heavy metals in the marine food-chain. Environ Int 32:191-198

Bilecen K, Yildiz FH (2009) Identification of a calcium controlled negative regulatory system affecting Vibrio cholerae biofilm formation. Environ Microbiol 11:2015-2029

Braissant O, Cailleau G, Dupraz C, Verrecchia EP (2003) Bacterially induced mineralization of calcium carbonate in terrestrial environments: the role of exopolysaccharides and amino acids. J Sed Res 73:485-490

Case RM, Eisner D, Gurney A, Jones O, Muallem S, Verkhratsky A (2007) Evolution of calcium homeostasis: from birth of the first cell to an omnipresent signaling system. Cell Calcium 42:345-350

Cruz LF, Parker JK, Cobine PA, De La Fuente L (2014) Calcium-enhanced twitching motility in Xylella fastidiosa is linked to a single PilY1 homolog. Appl Environ Microbiol 80:7176-7185

Davey ME, O'Toole GA (2000) Microbial biofilms: from ecology to molecular genetics. Microbiol Mol Biol Rev 64:847-867

Diaz-Ochoa VE, Jellbauer S, Klaus S, Raffatellu M (2014) Transition metal ions at the crossroads of mucosal immunity and microbial pathogenesis. Front Cell Infect Microbiol 4:2. https://doi.org/10.3389/fcimb.2014.00002

Dominguez DC (2004) Calcium signalling in bacteria. Mol Microbiol 54:291-297

Dominguez DC, Guragain M, Patrauchan M (2015) Calcium binding proteins and calcium signaling in prokaryotes. Cell Calcium 57:151-165

Douglas S, Beveridge TJ (1998) Mineral formation by bacteria in natural microbial communities. FEMS Microbiol Ecol 26:79-88

Dupraz C, Reid RP, Braissant O, Decho AW, Norman RS, Visscher PT (2009) Processes of carbonate precipitation in modern microbial mats. Earth Sci Rev 96:141-162

Edlund A, Yang Y, Yooseph S, Hall AP, Nguyen DD, Dorrestein PC, Neison KE, He X, Lux R, Shi W, McLean JS (2015) Meta-omics uncover temporal regulation of pathways across oral microbiome genera during in vitro sugar metabolism. ISME J 9:2605-2619

Ehrlich HL (1997) Microbes and metals. Appl Microbiol Biotechnol 48:687-692

Elias S, Banin E (2012) Multi-species biofilms: living with friendly neighbors. FEMS Microbiol Rev 36:990-1004

Gallegos-Monterrosa R, Kankel S, Götze S, Barnett R, Stallforth P, Kovács ÁT (2017) Lysinibacillus fusiformis M5 induces increased complexity 
in Bacillus subtilis 168 colony biofilms via hypoxanthine. J Bacteriol 199:e00204-e00217

Ganendra G, De Muynck W, Ho A, Arvaniti EC, Hosseinkhani B, Ramos JA, Rahier H, Boon N (2014) Formate oxidation-driven calcium carbonate precipitation by Methylocystis parvus OBBP. Appl Environ Microbiol 80:4659-4667

Giuffre AJ, Hamm LM, Han N, De Yoreo JJ, Dove PM (2013) Polysaccharide chemistry regulates kinetics of calcite nucleation through competition of interfacial energies. Proc Natl Acad Sci USA 110:9261-9266

Guragain M, Lenaburg DL, Moore FS, Reutlinger I, Patrauchan MA (2013) Calcium homeostasis in Pseudomonas aeruginosa requires multiple transporters and modulates swarming motility. Cell Calcium 54:350-361

Hall-Stoodley L, Costerton JW, Stoodley P (2004) Bacterial biofilms: from the natural environment to infectious diseases. Nat Rev Microbiol 2:96-108

Hammes F, Verstraete W (2002) Key roles of pH and calcium metabolism in microbial carbonate precipitation. Rev Environ Sci Biotechnol 1:3-7

Islam MS (2012) Calcium signaling. Springer, New York

Johnson MD, Garrett CK, Bond JE, Coggan KA, Wolfgang MC, Redinbo MR (2011) Pseudomonas aeruginosa PilY1 binds integrin in an RGD- and calcium dependent manner. PLoS ONE 6:e29629

Knoll AH (2003) Biomineralization and evolutionary history. Rev Mineral Geochem 54:329-356

Lee YS, Park W (2018) Current challenges and future directions for bacterial self-healing concrete. Appl Microbiol Biotechnol 102:3059-3070

Lee YS, Kim HJ, ParkW (2017) Non-ureolytic calcium carbonate precipitation by Lysinibacillus sp. YS11 isolated from the rhizosphere of Miscanthus sacchariflorus. J Microbiol. 55:440-447

Liu YL, Nascimento M, Burne RA (2012) Progress toward understanding the contribution of alkali generation in dental biofilms to inhibition of dental caries. Int J Oral Sci 4:135-140

Liu W, Roder HL, Madsen JS, Bjarnsholt T, Sorensen SJ, Burmolle M (2016) Interspecific bacterial interactions are reflected in multispecies biofilm spatial organization. Front Microbiol 7:1-8

Nadell CD, Drescher K, Foster KR (2016) Spatial structure, cooperation and competition in biofilms. Nat Rev Microbiol 14:589-600

Norris V, Grant S, Freestone P, Canvin J, Sheikh FN, Toth I, Trinei M, Modha

K, Norman RI (1996) Calcium signalling in bacteria. J Bacteriol

178:3677-3682
O'Toole GA (2011) Microtiter dish biofilm formation assay. JVis Exp 30:2437. https://doi.org/10.3791/2437

Paerl HW, Timothy FS, Pamela Reid R (2001) Bacterially mediated precipitation in marine stromatolites. Environ Microbiol 3:123-130

Porsch EA, Johnson MD, Broadnax AD, Garrett CK, Redinbo MR, St Geme JW 3rd (2013) Calcium binding properties of the Kingella kingae PilC1 and PilC2 proteins have differential effects on type IV pilus-mediated adherence and twitching motility. J Bacteriol 195:886-895

Riding R (2000) Microbial carbonates: the geological record of calcified bacterial-algal mats and biofilms. Sedimentology 47:179-214

Rigden DJ, Woodhead DD, Wong PWH, Galperin MY (2011) New structural and functional contexts of the Dx[DN]xDG linear motif: insights into evolution of calcium binding proteins. PLoS ONE 6:e21507

Roane TM, Rensing C, Pepper IL, Maier RM (2009) Microorganisms and metal pollutants. In: Maier RM, Pepper IL, Gerba CP (eds) Environmental microbiology. Elsevier/Academic Press, Amsterdam; Boston, pp 421-444

Sarkisova S, Patrauchan MA, Berglund D, Nivens DE, Franklin MJ (2005) Calcium-induced virulence factors associated with the extracellular matrix of mucoid Pseudomonas aeruginosa biofilms. J Bacteriol 187:4327-4337

Shemarova IV, Nesterov VP (2005) Evolution of $\mathrm{Ca}^{2+}{ }^{2}$-signaling mechanisms: role of calcium ions in signal transduction in lower eukaryotes. J Evol Biochem Phys 41:377-390

Tourney J, Ngwenya BT (2009) Bacterial extracellular polymeric substances (EPS) mediate $\mathrm{CaCO}_{3}$ morphology and polymorphism. Chem Geol 262:138-146

Yan W, Xiao X, Zhang Y (2017) Complete genome sequence of Lysinibacillus sphaericus LMG 22257, a strain with ureolytic activity inducing calcium carbonate precipitation. J Biotechnol 246:33-35

Zhang T, Klapper I (2010) Mathematical model of biofilm induced calcite precipitation. Water Sci Technol 61:2957-2964

Zhou Y, Yang W, Kirberger M, Lee HW, Ayalasomayajula G, Yang JJ (2006) Prediction of EF-hand calcium-binding proteins and analysis of bacterial EF-hand proteins. Proteins 65:643-655

Zhu T, Dittrich M (2016) Carbonate precipitation through microbial activities in natural environment, and their potential in biotechnology: a review. Front Bioeng Biotechnol 4:4

\section{Submit your manuscript to a SpringerOpen ${ }^{\circ}$ journal and benefit from:}

- Convenient online submission

- Rigorous peer review

- Open access: articles freely available online

- High visibility within the field

Retaining the copyright to your article

Submit your next manuscript at $\boldsymbol{\nabla}$ springeropen.com 